\title{
Posaconazole prophylaxis in patients with acute myeloid leukemia: A real life experience from a prospective multicenter observational study
}

\author{
Gökhan Metan 1 , afpTürkiye study group ( 34 investigators from 18 centers) \& Hamdi Akan ${ }^{2,3}$
}

${ }^{1}$ Department of Infectious Diseases and Clinical Microbiology, Faculty of Medicine, Hacettepe University, Ankara, Turkey, ${ }^{2} \mathrm{Clinical}$ Research Unit,and ${ }^{3}$ Department of Hematology, Faculty of Medicine, Ankara University, Ankara, Turkey

Background: We aimed to investigate the effectivity of posaconazole prophylaxis $(\mathrm{PP})$ in patients receiving induction chemotherapy for acute myeloid leukemia (AML) at Turkish hospitals.

Patients and methods: Patients $\geq 18$-years who received chemotherapy for AML with a duration of neutropenia $(<500$ cells $/ \mathrm{mm} 3$ ) $\geq 10$ days were included in a prospective multicenter observational study. Patients were followed until one week after recovery from neutropenia or discharge from hospital (for patients who were not recovered from neutropenia) to define the success of PP. Survival was followed up to six months. Each patient was allowed to be included for only one chemotherapy cycle.Prophylaxis failure was defined as; (1) the occurrence of invasive fungal diseases (IFDs) identified according to European Organization for Research and Treatment of Cancer and the Mycoses Study Group (EORTC/MSG) criteria ${ }^{1}$, (2) receipt of any other systemic antifungal agent for 4 days or more during febrile neutropenia episode without any identified IFDs, (3) the occurrence of an adverse event related to the posaconazole resulting in the discontinuation of posaconazole, (4) Death for any cause under PP. Each patient was allowed to be included for only one chemotherapy cycle. The exclusion criteria were as; previous history of IFD, switch to an other antifungal before 7-days of PP except in case of toxicity related to posaconazole and duration of neutropenia $<10$ days. Groups (according to the outcome of PP) were compared with the use of Chi square and Fisher's exact tests for categorical variables, and Mann-Whitney $U$ test for continuous vathe riables

Results:

- A total of 115 patients were recruited from 18 centers between 21 November 2015 and 01 June 2016 (Table 1)

- Ninety-nine patients received first induction chemotherapy..

- Daunorubicin/idarubicin combined with cytarabine was the choice of chemotherapy in 98 patients

- All patients received $200 \mathrm{mg}$ of posaconazole in an oral suspension three times daily.

- Median duration of PP was 25 days (Inter quartile range IQR; 1735).

- PP was successful in 76 (66.1\%) patients.

- The reasons for failure were as; initiation of an other antifungal drug for persistent neutropenic fever in 7 patients, breakthrough IFDs in 15 patients (possible IFD in 8 patients, probable invasive aspergillosis in 5 patients, proven IFDs in 2 patients), unable to take oral drug in 2 patients, Non-spesific pulmonary findings with prolonged fever in 3 patients and death under PP in 8 patients. Adverse events related to PP were reported in 6 patients.

- The overall mortality was $15.7 \%$ (18 out of 115 patients) $12-$ weeks after initiation of PP
Table 1. Clinical and demographic characteristics of the patients

\begin{tabular}{|c|c|c|c|}
\hline & $\begin{array}{l}\text { Success } \\
(n=76) \%\end{array}$ & $\begin{array}{l}\text { Failure } \\
(n=39) \%\end{array}$ & $\mathbf{p}$ \\
\hline Age (median(IQR)) (years) & $\begin{array}{c}46,0 \\
(32,0-60,75)\end{array}$ & $\begin{array}{r}51,0 \\
(37,0- \\
60,0) \\
\end{array}$ & NS \\
\hline Male & $41(53,9)$ & $22(56,4)$ & NS \\
\hline $\begin{array}{l}\text { Duration of neuropenia } \\
\text { (median(IQR)) days }\end{array}$ & $\begin{array}{c}22,0 \\
(18,0-29,0)\end{array}$ & $\begin{array}{c}26,5 \\
(19,75- \\
37,5)\end{array}$ & NS \\
\hline $\begin{array}{l}\text { Patients who did not } \\
\text { recover from neutropenia }\end{array}$ & - & $13(33.3)$ & \\
\hline $\begin{array}{l}\text { Factors related to the } \\
\text { posaconazole absorbtion } \\
\text { - Fatigue } \\
\text { - Vomitting } \\
\text { - Diarrhea } \\
\text { - Gastrointestinal mucositis } \\
\text { - Lipid rich diet } \\
\text { - Use of H2 receptor blocker } \\
\text { - Use of proton pump } \\
\text { inhibitor }\end{array}$ & $\begin{array}{c}22(28,9) \\
5(6,6) \\
10(13,2) \\
16(21,0) \\
13(17,1) \\
13(17,1) \\
39(51,3)\end{array}$ & $\begin{array}{c}15(38,5) \\
7(17,9) \\
8(20,5) \\
7(17,9) \\
9(23,1) \\
5(12,8) \\
16(41,0)\end{array}$ & $\begin{array}{l}\text { NS } \\
\text { NS } \\
\text { NS } \\
\text { NS } \\
\text { NS } \\
\text { NS } \\
\text { NS }\end{array}$ \\
\hline $\begin{array}{l}\text { - Smoking } \\
\text { - Duration of smoking (pack- } \\
\text { years) (median, (IQR)) }\end{array}$ & $\begin{array}{c}18 /(23,7) \\
27,5 \\
(20,0-40,0)\end{array}$ & $\begin{array}{c}10(25,6) \\
17,5 \\
(10,0- \\
30,0) \\
\end{array}$ & $\begin{array}{l}\text { NS } \\
\text { NS }\end{array}$ \\
\hline Leaving in a rural area & $14 /(18,4)$ & $3(7,7)$ & NS \\
\hline $\begin{array}{l}\text { Receipt of care at HEPA } \\
\text { filtered room }\end{array}$ & $26(34,2)$ & $6(15,4)$ & 0.047 \\
\hline $\begin{array}{l}\text { Receipt of care at a positive } \\
\text {-pressured and HEPA } \\
\text { filtered room }\end{array}$ & $18(23,7)$ & $5(12,8)$ & NS \\
\hline $\begin{array}{l}\text { Construction close to the } \\
\text { ward when patient was } \\
\text { neutropenic }\end{array}$ & $25(32,9)$ & $16(41,0)$ & NS \\
\hline $\begin{array}{l}\text { Number of erythrocyte } \\
\text { transfusions (median, (IQR)) }\end{array}$ & $\begin{array}{c}8,0 \\
(4,25-12,0) \\
\end{array}$ & $\begin{array}{c}6,0 \\
(4,0-10,0) \\
\end{array}$ & NS \\
\hline $\begin{array}{l}\text { Exposure outside the } \\
\text { hematology or stem cell } \\
\text { transplantation ward during } \\
\text { neutropenic period } \\
\text { (median(IQR)) }\end{array}$ & $\begin{array}{c}4,0 \\
(2,0-7,0)\end{array}$ & $\begin{array}{c}2,0 \\
(1,0-7,0)\end{array}$ & NS \\
\hline $\begin{array}{l}\text { Nystatin suspension } \\
\text { prophylaxis }\end{array}$ & $46(60,5)$ & $24(61,5)$ & NS \\
\hline $\begin{array}{l}\text { Duration of PP (median, } \\
\text { IQR) (days) }\end{array}$ & $\begin{array}{c}26,0 \\
(22,0-34,75)\end{array}$ & $\begin{array}{c}16,0 \\
(9,0-36,0)\end{array}$ & $<0.001$ \\
\hline $\begin{array}{l}\text { Initiation of PP after } \\
\text { cytotoxic chemotherapy }\end{array}$ & $26(34,2)$ & $17(43,6)$ & NS \\
\hline $\begin{array}{l}\text { 12-weeks mortality after } \\
\text { initiation of PP }\end{array}$ & $3 / 76(14,0)$ & $15(39,5)$ & $<0.001$ \\
\hline $\begin{array}{l}\text { 24-weeks mortality after } \\
\text { initiation of PP }\end{array}$ & $4 / 73(4,2)$ & $2 / 24(8,3)$ & NS \\
\hline
\end{tabular}

IQR; Interquartile range, NS; not significant, PP; posaconazole prophylaxis

\section{Conclusion}

PP is widely used in our hospitals. Despite the acceptable rate of efficacy, better standardized strategies are required to improve the overall success of

Acknowledgement: This study was supported by Gilead Turkey fellowship programme with an unrestricted educational grant

Reference: :1. De Pauw B, et al. Clin Infect Dis 2008; 46:1813-1821. 